\title{
IMPLIKASI PELAKSANAAN PERJANJIAN JUAL BELI TELEPON SELULER ILEGAL (BLACK MARKET) ${ }^{*}$
}

\author{
Andika Prawira Buana ${ }^{1}$, Hasnan Hasbi ${ }^{2}$, Muhammad Kamal ${ }^{3}$, Aan Aswari ${ }^{4}$ \\ Fakultas Hukum, Universitas Muslim Indonesia, Urip Sumharjo No 5, Makassar \\ e-mail: andika.prawira@umi.ac.id ${ }^{1}$ \\ e-mail: hasnan.hasbi@umi.ac.id ${ }^{2}$ \\ e-mail: muhkamal.hidjaz@umi.ac.id ${ }^{3}$ \\ e-mail: aanaswari@umi.ac.id ${ }^{4}$
}

\begin{abstract}
An agreement is a legal relationship between one person and another person or several persons in order to accomplish a certain thing that has been agreed upon. The Agreement becomes the Law for the parties who make and comply with the content of the agreement. In principle, the treaty embraces the principle of contractual freedom, but that freedom has certain limitations that cannot be violated for the sake of justice, usefulness and legal certainty. The purpose of this research is to describe juridically the wetness and consequences of the illegal cell phone sale and purchase agreement. This research method uses normative legal research type using secondary data and is analyzed based on juridical descriptive. The results of this study argue that the absence of a mobile phone sale agreement is illegal because it does not meet the legal requirements of the agreement which is lawful under the applicable positive law and that the agreement is declared void by law and is considered to be a non-binding agreement.
\end{abstract}

Keywords: Implications; Purchase Agreement; Mobile Phone.

\begin{abstract}
Abstrak
Perjanjian merupakan suatu hubungan hukum antara satu orang dengan orang lain atau beberapa orang untuk melaksanakan suatu hal tertentu yang telah disepakati. Perjanjian menjadi Undang-undang bagi para pihak yang membuat serta tunduk pada isi perjanjian tersebut. Pada prinsipnya perjanjian menganut asas kebebasan berkontrak, akan tetapi kebebasan itu memiliki batasan yang tidak boleh dilanggar demi terwujudnya keadilan, kemanfaatan dan kepastian hukum. Tujuan penelitian ini untuk mendeskripsikan secara yuridis kebasahan dan akibat dari perjanjian jual beli telepon seluler ilegal. Metode penelitian ini menggunakan tipe penelitian hukum normatif dengan menggunakan data sekunder dan dianalisis berdasarkan deskriptif yuridis. Hasil penelitian ini menjawab bahwa tidak absahnya perjanjian jual beli telepon seluler ilegal karena tidak terpenuhinya syarat sah perjanjian yakni kausa yang halal menurut hukum positif yang berlaku dan perjanjian tersebut dinyatakan batal demi hukum serta dianggap perjanjian tidak pernah terjadi.
\end{abstract}

Kata Kunci: Implikasi; Perjanjian Jual Beli; Telepon Seluler.

\footnotetext{
* Naskah diterima: 27Juni 2020, direvisi: 18 September 2020, disetujui untuk terbit: 29 September 2020

Doi: $10.3376 /$ jch.v6i1.287
} 
Andika Prawira Buana, Hasnan Hasbi, Muhammad Kamal, Aan Aswari: Implikasi...

\section{PENDAHULUAN}

Perkembangan sistem informasi dan teknologi dianggap sebagai angin segar karena memberikan dampak positif terhadap masyarakat, khususnya dalam penggunaan Telepon Seluler. Sebagai salah satu alat pendukung perkembangan sistem tersebut. Tingginya minat masyarakat terhadap penggunaan Telepon Seluler memiliki dampak positif dari aspek ekonomi, akan tetapi juga memiliki dampak negatif dari aspek hukum. Meningkatnya aktivitas jual beli Telepon

Seluler tentu menjadikan proses produksi hingga proses distribusi alat tersebut tidak lagi melalui proses yang baik dan legal secara hukum. Bukti konkret dampak negatif tersebut adalah meningkatnya peredaran Telepon Seluler illegal atau black market di masyarakat (Dimas Ryandi, diakses 09 Juni 2019). Peredaran ponsel illegal atau black market itu dianggap oleh sebagian masyarakat sebagai solusi atas mahalnya produkproduk Telepon Seluler legal yang dikeluarkan oleh gerai distributor resmi. Akan tetapi, masyarakat tidak memahami akibat hukum yang timbul atas pembelian Telepon Seluler ilegal atau black market tersebut. Jenis kerugian yang nyata adalah potensi kerugian terhadap penerimaan pajak dari penjualan telepon seluler tersebut. Mahkamah Agung dalam Putusan perkara Nomor: 527 k/Pdt/2006 secara gamblang menggunakan istilah black market untuk menyebutkan suatu bentuk perdagangan yang tidak resmi. Telepon seluler termasuk produk telekomunikasi dan elektronik sebagaimana diatur dalam Peraturan Menteri Perdagangan Nomor: 19/MDAG/PER/5/2009. Menurut ketentuan Pasal 2 ayat (1) Permendag 19/MDAG/PER/5/2009 yang menyebutkan bahwa: "Setiap produk telekomunikasi dan elektronik yang diproduksi dan/atau diimpor untuk diperdagangkan di pasar dalam negeri wajib dilengkapi dengan petunjuk pengguna dan kartu jaminan (garansi purna jual) dalam Bahasa Indonesia". Terhadap penjual telepon seluler yang menyalahi ketentuan Pasal 2 ayat (1) Peraturan Menteri Perdagangan Nomor 19/M-DAG/PER/5/2009 berlaku ketentuan Pasal 22 Permen 19/MDAG/PER/5/2009 yang menyatakan bahwa "pelaku usaha yang melanggar ketentuan sebagaimana dimaksud dalam pasal 2 ayat (1), dikenakan sanksi sebagaimana diatur dalam UndangUndang Nomor 8 Tahun 1999 tentang Perlindungan Konsumen". Berdasarkan peraturan dalam Pasal 62 ayat (1) jo. Pasal 8 ayat (1) UUPK penjual telepon seluler yang dengan tidak memberikan kartu garansi serta layanan purna jual dapat dikenai sanksi. (Gde Manik Yogiartha, 2011)

Hal yang menjadi persoalan kemudian adalah masyarakat selaku konsumen cenderung menuntut hak yang sama seperti hak-hak yang diberikan oleh gerai distributor resmi kepada setiap pembelian Telepon Seluler secara resmi. Hak-hak yang dituntut tersebut antara lain adalah layanan purna jual (garansi distributor resmi) ketika Telepon Seluler yang dibeli mengalami kerusakan di 
kemudian hari, padahal Telepon Seluler illegal hanya menawarkan layanan purna jual dengan garansi toko. Akan tetapi, atas dasar kesepakatan terhadap perjanjian jual beli Telepon Resmi illegal tersebut, masyarakat atau konsumen merasa memiliki hak yang diatur dan dilindungi oleh Undang-Undang Nomor 8 Tahun 1999 tentang Perlindungan Konsumen.

UUPK pada dasarnya memberikan perlindungan kepada konsumen yang tertuang dalam Pasal 7 huruf e, "memberi kesempatan kepada konsumen untuk menguji, dan/atau mencoba barang dan/atau jasa tertentu serta memberi jaminan dan/atau garansi atas barang yang dibuat dan/atau yang diperdagangkan". Akan tetapi, menurut penelitian ini hak tersebut sulit untuk didapatkan sebab, tidak adanya kepastian hukum yang diperoleh pihak konsumen/masyarakat karena hanya berdasar pada perjanjian jual beli yang kebesahannya masih dipertanyakan karena bertentangan dengan Pasal 1320 KUHPerdata yang mengatur mengenai syarat sah nya perjanjian dimana salah satu syaratnya ialah suatu sebab yang halal. Suatu sebab yang halal tersebutlah yang menjadi poin penting untuk dianalisis lebih lanjut, apakah Telepon Seluler black market merupakan suatu hal yang dilarang menurut hukum positif karena menyebabkan sulitnya masyarakat /konsumen untuk melakukan tuntutan melalui jalur litigasi serta mendapatkan hak-hak sebagai konsumen. Berdasarkan penjabaran diatas, maka penelitian ini mengambil sebuah masalah yang menjadi fokus penelitian adalah bagaimanakah implikasi pelaksanaan perjanjian jual beli telepon seluler ilegal atau black market.

\section{METODE PENELITIAN}

Tipe penelitian ini adalah tipe penelitian hukum normatif yang mengkaji aturan perundang-undangan serta doktrin dan artikel hukum yang berkaitan dengan penelitian ini. Penelitian ini menggunakan data sekunder yang terdiri dari bahan hukum primer, bahan hukum sekunder dan bahan hukum tersier, kemudian dianalisis berdasarkan deskriptif yuridis.

\section{HASIL DAN PEMBAHASAN}

\section{Syarat Sah Perjanjian dan Implikasinya}

Perjanjian merupakan suatu hubungan hukum antara satu orang dengan orang lain atau beberapa orang untuk melaksanakan suatu hal tertentu yang telah disepakati. Menurut Pasal 1313 KUHPerdata Suatu persetujuan adalah suatu perbuatan dimana satu orang atau lebih mengikatkan diri terhadap satu orang lain atau lebih. Perbuatan hukum dalam perjanjian merupakan suatu perbuatan untuk menyerahkan sesuatu, melakukan sesuatu dan tidak melakukan sesuatu karena melekatnya hak dan kewajiban atau secara umum dikenal dengan istilah prestasi. Perbuatanperbuatan dalam perjanjian tersebut menghasilkan sebuah perikatan yang harus dipenuhi oleh masing-masing pihak dan tunduk dalam perjanjian yang telah dibuat. Setiap pihak tidak boleh melakukan wanprestasi terhadap ketentuan yang tertuang dalam perjanjian, 
Andika Prawira Buana, Hasnan Hasbi, Muhammad Kamal, Aan Aswari: Implikasi...

karena adanya sanksi perdata yang sesuai dengan ketentuan Pasal 1365 KUHPerdata. Pasal 1365 KUHPerdata menjelaskan bahwa "Tiap perbuatan yang melanggar hukum dan membawa kerugian kepada orang lain, mewajibkan orang yang menimbulkan kerugian itu karena kesalahannya untuk menggantikan kerugian tersebut". Pada hakikatnya perjanjian yang dibuat dilaksanakan secara bebas untuk mengadakan perjanjian baik yang diatur dalam undangundang atau pun yang belum diatur. Akan tetapi, kebebasan tersebut dibatasi oleh beberapa hal, yakni tidak dilarang oleh undang-undang, tidak bertentangan dengan kepentingan umum dan tidak bertentangan dengan kesusilaan. Oleh sebabnya setiap perjanjian yang akan dibuat, tetap harus memperhatikan aturanatruan yang tidak dilarang dan sesuai dengan Peraturan Perundang-undangan yang berlaku

Pasal 1320 KUH Perdata disebutkan, untuk sahnya suatu perjanjian diperlukan empat syarat, yaitu:

a. Sepakat mereka yang mengikatkan dirinya, artinya bahwa para pihak yang mengadakan perjanjian itu harus bersepakat atau setuju mengenai perjanjian yang akan diadakan tersebut, tanpa adanya paksaan, kekhilafan dan penipuan.

b. Kecakapan, yaitu bahwa para pihak yang mengadakan perjanjian harus cakap menurut hukum, serta berhak dan berwenang melakukan perjanjian.

c. Mengenai suatu hal tertentu, hal ini maksudnya adalah bahwa perjanjian tersebut harus mengenai suatu obyek tertentu. d. Suatu sebab yang halal, yaitu isi dan tujuan suatu perjanjian haruslah berdasarkan hal-hal yang tidak bertentangan dengan undangundang, kesusilaan dan ketertiban. (Yayan Hanapi, 2018)

Syarat-syarat tersebutlah yang wajib dipenuhi oleh setiap pihak dalam pembuatan perjanjian. Jika salah satu syarat tidak terpenuhi perjanjian tersebut dapat dibatalkan dan batal demi hukum.

Perjanjian jual beli pada dasarnya menurut Pasal 1457 KUHPerdata jual beli adalah suatu persetujuan dengan mana pihak yang satu mengikatkan dirinya untuk menyerahkan suatu barang dan pihak yang lain untuk membayar harga yang dijanjikan. (Djaja S Meliala, 2012) Secara hakikat perjanjian jual beli itu terjadi ketika tercapainya kata sepakat antara penjual dan pembeli dan terpenuhinya semua prestasi yang melekat pada masing-masing pihak. Kata sepakat tersebut telah memenuhi unsur syarat sah nya perjanjian, yang mewajibkan adanya kesepakatan agar perjanjian jual beli itu sah meskipun barang itu belum serahkan dan harganya belum dibayar (Umul Khair, 2017).

Perjanjian secara filosofis merupakan hak dan kewajiban yang dianggap sakral karena bersumber dari ekspresi atau asas yang menyatakan bahwa perjanjian itu dibuat secara bebas dan sukarela. Perjanjian dibuat berdasarkan kemauan sendiri dari masing-masing pihak dan secara sadar menyatakan perjanjian itu wajib untuk dipenuhi (Ridwan Khairandy, 2011). Dalam hukum kontrak terdapat 5 (tiga) asas yang saling berkaitan, yaitu 
asas konsensualisme (the principle of consensualism), asas kebebasan berkontrak (the principle of freedom of contract), asas kepastian hukum (the legal binding of contract), asas itikad baik (the principle of good faith) dan asas kepribadian (the principle of personality). Asas-asas tersebut yang menjadi dasar filosofis bagi para pihak untuk secara sadar dan sukarela membuat dan menentukan isi perjanjian (Niru Anita Sinaga, 2018).
Hukum positif mengatur syarat sah nya perjanjian yang wajib termuat dalam setiap isi perjanjian yang akan dibuat, antara lain: 1. adanya kesepakatan para pihak, 2. adanya suatu hal tertentu, 3 . cakap menurut hukum dan 4. hal yang diperjanjikan merupakan suatu sebab yang halal menurut hukum positif. Syarat tersebut kemudian terbagi lagi menjadi syarat subjektif dan syarat objektif yang antara lain:

\begin{tabular}{clc}
\hline \multicolumn{1}{c}{ Syarat } & \multicolumn{1}{c}{ Syarat Sah } & \multicolumn{1}{c}{ Implikasi } \\
\hline Syarat subjektif & - Kesepakatan para pihak & Dapat dibatalkan \\
& - Cakap menurut hukum & \\
Syarat objektif & - Adanya hal tertentu & Batal demi hukum \\
& - Suatu sebab yang halal menurut hukum & \\
\hline
\end{tabular}

Implikasi dapat dibatalkan jika syarat subjektif dalam perjanjian tidak terpenuhi namun perjanjian tetap mengikat para pihak selamat tidak dibatalkan oleh hakim atas permintaan para pihak yang berhak untuk membatalkan perjanjian tersebut, sedangkan implikasi batal demi hukum jika syarat objektif dalam perjanjian tidak terpenuhi maka perjanjian tersebut dianggap tidak pernah ada. Penjelasan tersebut, secara gamblang menyatakan jika syarat syarat sah tersebut tidak terpenuhi akan berimplikasi hukum pada perjanjian yang dibuat dengan kata lain tidak terpenuhinya kepastian dan perlingungan hukum terhadap masingmasing pihak yang mengikatkan perjanjian.

\section{Keabsahan Perjanjian Jual Beli Telepon Seluler Ilegal}

Bertalian dengan penjelasan diatas dan yang menjadi fokus dalam penelitian ini penulis menyatakan bahwa perjanjian jual beli telepon seluler ilegal antara penjual dan pembeli dinyatakan batal demi hukum. Hal tersebut disandarkan pada analisis, perjanjian jual beli yang dibuat melanggar ketentuan syarat sah perjanjian berdasarkan ketentuan Pasal 1320 KUHPerdata. Syarat yang dilanggar tersebut adalah telepon seluler sebagai objek perjanjian bukan merupakan suatu sebab yang halal menurut hukum positif karena tidak memenuhi ketentuan perpajakan berdasarkan peraturan perundang-undangan yang berlaku. produsen telepon seluler ilegal tersebut memperoleh ponsel melalui importir secara tidak resmi dan terhindar dari biaya 
Andika Prawira Buana, Hasnan Hasbi, Muhammad Kamal, Aan Aswari: Implikasi...

cukai sehingga perolehan barang tersebut tergolong sebagai ponsel illegal. Ketentuan pemerintah Indonesia berdasarkan Peraturan Menteri Keuangan nomor PMK 199/PMK.10/2019, Bea Cukai menyesuaikan nilai pembebasan bea masuk atas barang kiriman dari sebelumnya USD 75 menjadi USD 3 per kiriman. Sedangkan pungutan pajak dalam rangka impor diberlakukan normal. Namun demikian pemerintah juga merasionalisasi tarif dari semula berkisar $\pm 27,5 \%-37,5 \%$ (bea masuk 7,5\%, PPN $10 \%$, PPh $10 \%$ dengan NPWP, dan PPh $20 \%$ tanpa NPWP) menjadi $\pm 17,5 \%$ (bea masuk 7,5\%, PPN 10\%, PPh 0\%), (www.beacukai.go.id/berita/siap-siapaturan-impor-barang-kiriman-terbarumulai-berlaku-30-januari-2020.html, diakses 17 Maret 2020).

Regulasi tersebutlah yang secara yuridis tidak sesuai dengan aturan distribusi produsen ponsel ilegal dengan importir, sehingga dapat disimpulkan bahwa jika konsumen membeli ponsel kepada produsen, maka status hukum perjanjian jual beli ponsel tersebut batal demi hukum. Konsumen harus dengan cermat melihat status hukum dari setiap barang yang akan dibeli, agar hak-hak konsumen tetap bisa terpenuhi dengan baik. Hal itu pun tertuang dalam Pasal 4 Undang-undang Nomor 8 Tahun 1999 tentang Perlindungan Konsumen. Terdapat beberapa hak konsumen yang sangat vital, mulai dari hak untuk memperoleh informasi yang jelas dan benar terkait barang tersebut juga adanya kompensasi dan ganti kerugian apabila barang yang diperjanjikan tidak sesuai. Undang-undang Perlindungan Konsumen pun mengatur mengenai perbuatan yang dilarang bagi pelaku usaha. Hal itu tertuang dalam Pasal 8 Undang-undang Nomor 8 Tahun 1999 tentang Perlindungan Konsumen. Pasal tersebut secara gamblang menyatakan bahwa pelaku usaha tidak boleh memperdagangkan atau tidak sesuai dengan standar yang dipersyaratkan dan ketentuan peraturan perundang-undangan.

KUHPerdata mengharuskan bahwa setiap perjanjian dikatakan sah jika memenuhi keempat syarat sah tersebut. (Novina Sri Indiraharti, 2016) Perjanjian terjadi tidak boleh ada unsur paksaan, khilaf dan penyalahgunaan keadaan (misbruik van omstandigheden). Dalam praktek jual beli telepon seluler ilegal memang tidak ada unsur-unsur yang dipraktekkan tersebut, akan tetapi yang menjadi fokusnya adalah objek atau suatu hal tertentu yang diperjanjikan bukan merupakan sebab yang halal menurut hukum positif. Syarat sahnya perjanjian pada syarat ke empat adalah suatu sebab yang halal menurut hukum positif, syarat tersebut adalah syarat objektif jika tidak terpenuhi maka perjanjian tersebut batal demi hukum. Dengan kata lain, syarat tersebut masuk kedalam unsur essensialia pada perjanjian, Unsur essensialia merupakan unsur perjanjian yang selalu harus ada di dalam suatu perjanjian. KUHPerdata menetapkan untuk sahnya perjanjian, selain dari harus ada klausulanya, klausula tersebut juga harus 
halal menurut hukum positif. (Aulia Gumilang Rusadi, 2020)

\section{Kerugian - Kerugian Jual Beli Telepon Seluler Ilegal}

Jual beli telepon seluler dalam penjabaran diatas, secara tegas menyatakan bahwa perjanjian tersebut batal demi hukum, dengan kata lain, hilangnya hubungan hukum antara penjual dan pembeli atau hilangnya hak dan kewajiban antara masing-masing pihak sebab perjanjian tersebut dianggap tidak pernah terjadi. Hilangnya hak dan kewajiban tersebut, tentu berdampak kerugian diantara para pihak. Menurut penulis, kerugian yang paling besar terjadi pada pembeli selaku konsumen, karena tidak adanya kepastian hukum yang diberikan untuk memberikan hak yang diatur berdasarkan peraturan perundangundangan. Selain pembeli/konsumen, negara juga mengalami kerugian yang besar dikarenakan hilangnya sumber pendapatan negara dari pajak pertambahan nilai dalam jual beli tersebut. Secara detail, kerugian-kerugian itu antara lain:

\section{a) Produk Tidak Terjamin Keasliannya}

Perilaku konsumen di Indonesia biasanya lebih memilih barang dengan harga murah dan menyampingkan kualitas dari barang tersebut. (Aditya Halim Perdana Kusuma, dkk, 2017) Telepon seluler yang notabenenya tidak memiliki garansi resmi dan pada umumnya telepon seluler tersebut merupakan ponsel impor dari luar negeri. Tentu, telepon seluler tersebut tidak melalui proses kualitas kontrol yang memenuhi standarisasi pabrik. Bisa saja, telepon seluler tersebut bukan asli melainkan hasil dari telepon seluler rekondisi bahkan palsu. Hal itu tentu bertentangan dengan Pasal 8 huruf e, Undang-undang Nomor 8 Tahun 1999 tentang Perlindungan Konsumen yang menyatakan pelaku usaha dilarang untuk memperdagangkan barang dan jasa yang tidak sesuai dengan mutu, tingkatan, komposisi, proses pengolahan, gaya, mode, atau penggunaan tertentu sebagaimana dinyatakan dalam label atau keterangan barang dan/atau jasa tersebut. Alasan tersebutlah yang menjadi dasar, jual beli telepon seluler itu tidak dibenarkan berdasarkan hukum dan aturan perundang-undangan yang berlaku.

\section{b) Produk Tidak Memiliki Garansi Distributor Resmi}

Pemberian garansi merupakan hal yang wajib dalam setiap pembelian telepon seluler. Prakteknya pemberian garansi ini terbagi, garansi distributor resmi, garansi distributor independen dan garansi toko. (Anisah Novitarani, dkk, 2016) Berdasarkan ketentuan Pasal 25 Undang-undang Nomor 8 Tahun 1999 tentang Perlindungan Konsumen, pelaku usaha yang memproduksi barang yang pemanfaatannya berkelanjutan dalam batas waktu sekurang-kurangnya 1 (satu) tahun wajib menyediakan suku cadang dan/atau fasilitas purna jual dan wajib memenuhi jaminan atau garansi sesuai dengan yang diperjanjikan. Ketentuan tersebutlah yang mengharuskan pelaku usaha memberikan garansi distributor resmi kepada konsumen. Akan tetapi, 
konsumen yang membeli telepon seluler ilegal hanya mendapatkan garansi toko, yang biasanya garansi ini hanya diberikan dengan kurun waktu 1 (satu) sampai 3 (tiga) bulan. Kurun waktu garansi itu menyalahi ketentuan Pasal 25 yang mengharuskan pemberian garansi sekurang-kurangnya 1 (satu) tahun kepada konsumen. Dalam prakteknya pula jika terjadi kerusakan suku cadang yang diberikan bukan merupakan suku cadang resmi yang direkomendasikan. Hal tersebut tentu memberikan kerugian yang besar terhadap konsumen.

\section{c) Produk Terdampak Regulasi Pemblokiran IMEI}

Pemerintah Indonesia bersama pihak operator seluler saat ini konsisten untuk melakukan pemblokiran International Mobile Equipment Identity (IMEI). Hal itu didasari bahwa besarnya kerugian yang dialami produsen telepon seluler resmi dan juga pemerintah karena kehilangan potensi pendapatan dari pajak pertambahan nilai. Kementrian Komunikasi dan Informatika, membeberkan potensi kerugian yang dialami negara dengan beredarnya telepon seluler black market atau telepon seluler ilegal. Menurut kominfo, ada potensi pendapatan negara berupa pajak yang tertahan sekitar Rp. 2 triliun per tahun. Oleh karena itu regulasi pemblokiran telepon seluler ilegal melalui IMEI akan membantu mengembalikan potensi sumber pajak tersebut. (Athika Rahma, diakses 18 Mei 2020) Regulasi tersebut diharapkan dapat terealisasi dengan baik, sehingga potensi kerugian yang dialami oleh produsen telepon seluler resmi dan negara dapat diminimalisir. Regulasi itu pula menjadi cambuk bagi konsumen telepon seluler yang tetap membeli ponsel illegal, dikarenakan ponsel illegal yang dibeli akan diblokir dan tidak dapat difungsikan di Indonesia. Hal itu tentu memberikan kerugian yang besar bagi konsumen.

\section{SIMPULAN}

Keabsahan perjanjian jaul beli telepon seluler ilegal berdasarkan KUHPerdata adalah batal demi hukum. Hal itu didasarkan pada tidak terpenuhinya syarat sah perjanjian berdasarkan Pasal 1320 KUHPerdata yakni objek yang diperjanjikan merupakan kausa yang tidak halal menurut peraturan perundang-undangan yang berlaku. Perjanjian jual beli yang dilakukan dianggap tidak pernah terjadi sehingga kepastian hukum bagi konsumen atau hak dan kewajiban konsumen tidak dapat terpenuhi. Hal itu, tentu memberikan kerugian materil yang besar bagi konsumen dan juga menghilangkan potensi pendapatan negara dari sumber pajak.

Konsumen dalam hal ini pembeli barang telepon seluler diharapkan untuk meningkatkan kesadaran hukum terkait ketentuan peraturan perundang-undangan. Hal itu bertujuan agar konsumen dapat mengetahui hak dan kewajibannya berdasarkan ketentuan undang-undang yang berlaku. Produsen resmi juga diharapkan untuk terus melakukan sosialisasi terkait product knowledge atau pengetahuan tentang produk telepon 
seluler resmi serta manfaat dari produk tersebut. Pemerintah juga diharapkan untuk konsisten terkait rencana pemblokiran IMEI agar mampu menghilangkan peredaran telepon seluler ilegal agar memberikan kepastian hukum kepada produsen resmi dan masyarakat sebagai konsumen serta mampu mengembalikan potensi pendapatan negara dari sumber pajak terhadap penjualan telepon seluler resmi.

\section{UCAPAN TERIMAKASIH}

Penulis mengucapkan terimakasih kepada Lembaga Penelitian dan Pengembangan Sumberdaya (LP2S) Universitas Muslim Indonesia yang telah mendanai penulisan artikel ini.

\section{DAFTAR PUSTAKA}

Athika Rahma. Potensi Kerugian Negara Akibat Ponsel Ilegal Capai Rp55 Miliar per Hari. https://www.merdeka.com/uang/pot ensi-kerugian-negara-akibat-ponselilegal-capai-rp-55-miliar-perhari.html. Diakses tgl 18 mei 2020.

Buana, A. P., Ma'ruf, T. A., \& Aswari, A. (2019). Harmonisasi Peraturan Perundang-undangan Terhadap Bentuk Perjanjian Melalui Telemarketing. Pleno Jure, 8(2), 4759.

DimasRyandi.https://www.jawapos.com/n asional/politik/06/11/2018/ponselbm-marak-di-pasaran-dpr-mintapemerintah-lakukan-ini/ (diakses, 09 Juni 2019).

Hanapi, Y. (2018). Analisis Perlindungan Konsumen Terkait Produk
Komputer Rakitan. Gorontalo Law

Review, 1(1), 100-114.

https://www.beacukai.go.id/berita/siapsiap-aturan-impor-barang-kirimanterbaru-mulai-berlaku-30-januari2020.html . (dikases tgl 17 Maret 2020).

Indiraharti, N. S. (2016). Aspek Keabsahan Perjanjian Dalam Hukum Kontrak (Suatu Perbandingan Antara Indonesia dan Korea Selatan). Jurnal Hukum PRIORIS, 4(1), 15-38.

Khair, U. (2017). Analisis Yuridis Perjanjian Pembiayaan Konsumen Dan Akibat Hukum Jika Terjadi Wanprestasi Dalam Perjanjian Pembiayaan Konsumen Di Indonesia. JCH (Jurnal Cendekia Hukum), 3(1), 32-45.

Khairandy, R. (2011). Landasan Filosofis kekuatan mengikatnya kontrak. Jurnal Hukum IUS QUIA IUSTUM, 18, 36-55.

Kitab Undang-Undang Hukum Perdata.

Meliala, D. S. (2012). Penuntun praktis hukum perjanjian khusus: jual-beli, sewa-menyewa, pinjam-meminjam. (Bandung: Nuansa Aulia).

Novitarani, A., \& Suradi, R. N. (2016). Analisis Garansi terhadap Perlindungan Konsumen dalam Jual Beli Telepon Seluler. Diponegoro Law Journal, 5(3), 1-17

Putra, A. H. P. K., Said, S., \& Hasan, S. (2017). Pengaruh Karakteristik Toko dan Produk bagi Konsumen di Indonesia terhadap Pembelian Impulsif. Jurnal Manajemen dan Kewirausahaan, 5(2). 
Andika Prawira Buana, Hasnan Hasbi, Muhammad Kamal, Aan Aswari: Implikasi...

Rosadi, A. G. (2020). Tanggung Jawab Notaris Dalam Sengketa Para Pihak Terkait Akta Perjanjian Pengikatan Jual Beli (Ppjb) Yang Dibuatnya. JCH (Jurnal Cendekia Hukum), 5(2), 243-259.

Sinaga, N. A. (2018). Peranan Asas-Asas Hukum Perjanjian Dalam Mewujudkan Tujuan Perjanjian. Binamulia Hukum, 7(2), 107-120.
Undang-Undang Nomor 8 Tahun 1999 tentang Perlindungan Konsumen.

Yogiartha, G. M., \& Griadhi, I. K. W. (2011). Perlindungan Hukum Terhadap Konsumen Dalam Jual Beli Telepon Seluler Tanpa Garansi di Pasar Gelap (Black Market). Jurnal Universitas Udayana Bali. 